\title{
Influence of Wine Grape Cultivars on Growth and Leaf Blade and Petiole Mineral Nutrients
}

\author{
Esmaeil Fallahi ${ }^{1}$, Bahman Shafii ${ }^{2}$, Jeffrey C. Stark $^{3}$, Bahar Fallahi ${ }^{4}$, \\ and Saad L. Hafez ${ }^{5}$
}

AdDitional INDEX wORDs. adaptability, leaf analysis, partitioning, Vitis

SumMARY. Cane growth, leaf blade area, blade and petiole fresh and dry weights and mineral nutrients of six grape (Vitis vinifera) cultivars were evaluated in 2000 and 2001 under climatic conditions of southwestern Idaho. The cultivars were: 'Barbera 02', 'Cabernet Sauvignon 02', 'Cabernet Sauvignon 04', 'Chardonnay 29', 'Merlot 01', and 'Sangiovese 04'. No differences were found in cane growth of different cultivars. 'Sangiovese 04' and 'Merlot 01' had larger leaf area and heavier leaves (both blades and petioles) and higher concentrations of blade nitrogen (N), while 'Merlot 01' and 'Chardonnay 29' had higher petiole nitrate$\mathrm{N}$ than all other cultivars. 'Merlot 01 ' had relatively the highest potassium (K) concentrations in both blade and petiole tissues. 'Chardonnay 29' had lower concentration of calcium (Ca) and 'Sangiovese 04' had lower concentrations of magnesium $(\mathrm{Mg})$ in both blade and petiole tissues than other cultivars although differences were not always significant. 'Barbera 02' had higher blade iron (Fe) and tended to have higher blade copper $(\mathrm{Cu})$ than other cultivars. However, 'Chardonnay 29' had higher petiole Fe than 'Barbera 02', 'Cabernet Sauvignon 04', and 'Sangiovese 04'. 'Merlot 01' had higher blade manganese (Mn) than 'Sangiovese 04'.

$\mathrm{W}$ ine grapes have been grown in southwestern Idaho since the early 1960s. In 1999, there were 266 ha of wine grapes in southwestern Idaho (Idaho Agricultural Statistics Service, 2003), increasing to approximately 445 ha in 2004 (personal knowledge). In spite of many favorable environmental conditions in southwestern Idaho, wine grapes in the region are subjected to the risk of severe winter injury in some years. However, since phylloxera (Phylloxera vitifoliae) has not been found in Idaho, most wine grapevines are established on their own roots. Thus, when severely low winter temperatures damage the upper portions of the vines, they may regrow and a new canopy can be established. Adaptability and fruit quality of wine grape cultivars in a region should be studied before they are widely

${ }^{1}$ Professor and Research Leader of Pomology Program, University of Idaho, Parma Research and Extension Center, 29603 U of I Lane, Parma, Idaho 83660.

${ }^{2}$ Professor of Plant Science and Director of Statistical Program, University of Idaho.

${ }^{3}$ Professor and Division Chair of Horticulture, Plant Physiologist, University of Idaho.

${ }^{4}$ Scientific Aid Senior, Pomology Program, University of Idaho.

${ }^{5}$ Professor and Director of Nematology Program, University of Idaho. planted, and several such studies were conducted for different regions of the U.S. (Adams, 1985; Cahoon, 1996; Fallahi et al., 2004, 2005; Hamman, 1993; Kaps and Odneal, 2001; Mielke, 1980; Pinney, 1989; Sexton, 1987; Wolf and Miller, 2001).

A considerable volume of information is available on the effects of fertilizer applications (Cook, 1966; Robinson, 1999), irrigation and canopy development (Robinson, 1999), and rootstock (Cook and Lider, 1964; Downton, 1977) on grape leaf mineral concentrations. Vine mineral nutrients in wine grapes not only influence yield and cane growth (Goldspink, 1987; Robinson, 1999; Weir, 1987; Winkler et al., 1974) but also affect wine quality (Amerine and Joslyn, 1970; Somers, 1975). There have been widely varied opinions among viticulturists for many years regarding the developmental stage, type of tissue (blade vs. petiole), and leaf position selected for mineral analysis; to best represent optimum nutrient status for wine grape growth and fruit quality (Cook, 1966; Robinson, 1999). The French Diagnostic Foliar laboratory at Montpellier relied upon leaf stalk (blade and petiole) tissue, sampled twice from each vineyard, one at bloom time and the other at veraison (Cook, 1966). A similar protocol is still practiced when more precise information on the foliar mineral status of a vineyard is needed (Pinney, 1989). However, following an early report by Ulrich (1942), petiole tissue alone, sampled at bloom time, is often used for mineral nutrients in California (Christensen, 1984; Cook and Lider, 1964). Also, for determination of nitrate- $\mathrm{N}$, a petiole sampling at anthesis is recommended in the Australian grape industry (Robinson, 1999).

In spite of the considerable commercial wine grape production and potential for expansion in the intermountain western U.S., there is limited information on the canopy growth, leaf size, and leaf mineral status of cultivars in the region. Therefore, the objective of this research was to study cane growth, leaf size, and leaf mineral nutrients in six wine grape cultivars grown under climatic conditions of southwestern Idaho (intermountain western U.S.).

\section{Materials and methods}

The experimental vineyard, consisting of six cultivars of wine grapes, was established at the University of Idaho Parma Research and Extension Center in southwestern Idaho in Spring 1998. The experimental vineyard was oriented at lat. $43^{\circ} 48^{\prime} 00^{\prime \prime}$ and long. $116^{\circ} 57^{\prime} 00^{\prime \prime}$ with 2305 - $\mathrm{ft}$ elevation. The site of the experimental vineyard had a long-term average annual precipitation of 10 inches with average minimum temperature of $19.2^{\circ} \mathrm{F}$ (in January) and maximum temperature of

\begin{tabular}{llll}
\hline $\begin{array}{l}\text { Units } \\
\text { To convert U.S. to SI, } \\
\text { multiply by }\end{array}$ & U.S. unit & SI unit & $\begin{array}{l}\text { To convert SI to U.S., } \\
\text { multiply by }\end{array}$ \\
\hline 0.3048 & $\mathrm{ft}$ & $\mathrm{m}$ & 3.2808 \\
3.7854 & $\mathrm{gal}$ & $\mathrm{L}$ & 0.2642 \\
2.5400 & inch(es) & $\mathrm{cm}$ & 0.3937 \\
6.4516 & inch $^{2}$ & $\mathrm{~cm}^{2}$ & 0.1550 \\
28.3495 & $\mathrm{oz}$ & $\mathrm{g}$ & 0.0353 \\
28,350 & $\mathrm{Oz}$ & $\mathrm{mg}$ & $3.5274 \times 10^{-5}$ \\
1 & $\mathrm{ppm}$ & ${ }^{\circ g} \cdot \mathrm{g}^{-1}$ & 1 \\
$\left({ }^{\circ} \mathrm{F}-32\right) \div 1.8$ & & ${ }^{\circ} \mathrm{C}$ & $\left(1.8 \times{ }^{\circ} \mathrm{C}\right)+32$
\end{tabular}


$92.1^{\circ} \mathrm{F}$ (in July). The cultivars were: 'Barbera 02', 'Cabernet Sauvignon 02', 'Cabernet Sauvignon 04', 'Chardonnay 29', 'Merlot 01', and 'Sangiovese 04'. All plant materials were obtained as No. 1 certified dormant cuttings with $1 / 4$ - to $3 / 4$-inch diameter and 14 inches long from Foundation Plant Materials Services (FPMS) at the University of California-Davis. Clones in this article are numbered by the FPMS. The experiment was arranged as a randomized completeblock design with four replications of eight vines per block. To induce roots on the cuttings, they were dipped in rooting compound (Earth Science Products Corp., Wilsonville, Ore.). A 2 - $\mathrm{ft}$-deep hole was dug in the ground, and about 13.3 inches of cuttings were buried in a damp soil with the basal ends upward. The rooting ends of cuttings were then covered with about 1-3/4 inches of fine sand and covered with black plastic, and sand was kept damp for about 6 weeks ( 5 Mar. to 18 Apr.). With this technique, the rooting end of each cutting was kept warm and moist, while the rest of the cutting was kept cooler. After 6 weeks, roots or callus were formed only on the rooting area, while the rest of the cutting was not as advanced.

The vines were planted at $7 \times 9$ $\mathrm{ft}$ spacing. The vineyard soil series was Truesdale fine sandy loam (classified as course-loamy), mixed, mesic Haploxerollic Durorthids with a $\mathrm{pH}$ of about 7.5. The soil was analyzed prior to planting and no plant parasitic nematodes were found. Therefore, the field was not treated with any nematicide. Pressure-treated wooden posts, $8 \mathrm{ft}$ long, were installed at $16-\mathrm{ft}$ spacing, with $6 \mathrm{ft}$ above the ground. One 7.5 - $\mathrm{ft}$ galvanized metal post (U-shape) was inserted $1.5 \mathrm{ft}$ into the ground next to each vine. Twelve-gauge galvanized wires were installed at 16, 42, and 50 inches from the ground as drip irrigation line wire, cordon wire, and catch wire, respectively. A 6-inch cross-arm was installed horizontally on each metal post at $5.5 \mathrm{ft}$ from the ground. Two parallel wires were installed, one on each side of the cross-arm, to keep the shoots in an upright position.

The vines remained uncut and grew as bushes during the first growing season. During the following dormant season (early March), two trunks per vine were selected and trained as a bilateral cordon system as described by Wample (1999). Each cordon arm was spur-pruned to leave six to eight spurs of two buds (for red wine grapes) and three buds for 'Chardonnay 29', not counting the basal buds, during the dormant season (early March) of each year. During May of each year, new shoots were thinned out to leave an approximately 3 - to 4 -inch space between shoots of each arm for better light penetration and air movement, and all downward growing shoots were also removed. Some of the shoots were positioned upward between the two wires on the cross-arms during each growing season.

A drip line was installed on the lowest wire with two $1 \mathrm{gal} / \mathrm{h}$ emitters per vine to deliver a total of $2 \mathrm{gal} / \mathrm{h}$ water per vine. Each emitter was placed 7 inches away from the vine trunk. Vines were irrigated when needed as indicated by a WaterMark Soil Moisture meter and sensor (Irrometer Co., Riverside, Calif.) and/or neutron probes based on personal experience for southern Idaho (E. Fallahi and T. Steiber, unpublished data) and as described by Shock et al. (1998), Evans (1999), Evans et al. (1993), and Wample (1999). During summer months, each vine received approximately 8 to $12 \mathrm{gal} /$ week in 1998 and $1999,16 \mathrm{gal} /$ week in 2000, and 20 $\mathrm{gal} /$ week in 2001 .

The vineyard was fertilized in late June (during active shoot growth) with $\mathrm{N}$ as urea $(46 \mathrm{~N}-0 \mathrm{P}-0 \mathrm{~K})$ during 1998 and 1999 and as urea plus mono ammonium phosphate ( $11 \mathrm{~N}-22.7 \mathrm{P}-0 \mathrm{~K})$ during 2000 and 2001. These fertilizers provided actual $\mathrm{N}$ at rates of 0.6 , $2.57,6.71$, and $11.65 \mathrm{~g} /$ vine in 1998, 1999, 2000, and 2001, respectively. The mono ammonium phosphate also supplied $P$ at actual rates of $5.60 \mathrm{~g} /$ vine in 2000 and $9.72 \mathrm{~g} /$ vine in 2001 . Vines also received $\mathrm{K}$ as potassium chloride $(0 \mathrm{~N}-0 \mathrm{P}-49.8 \mathrm{~K})$ at actual $\mathrm{K}$ rates of $6.72 \mathrm{~g} /$ vine in 2000 and $11.67 \mathrm{~g} /$ vine in 2001 in late June. All fertilizers were applied once per year to the soil, in a $\mathrm{l}$-ft radius area around each vine. No micronutrients were added to the vines in this experiment.

Weeds between vines were controlled mechanically by hand during the first 2 years of planting, and thereafter, by application of glyphosate (Roundup; Monsanto Technology LLC., St. Louis) in mid-June and mid-July every year. The vineyard floor was disked three times per year and kept clean. No pesticide was applied as no insect damage was observed. Vines were sprayed with sulfur (Sulfur DF; Wilbur-Ellis, Co., Fresno, Calif.) once or twice per year to control grape powdery mildew (Uncinula necator).

Length of one average-size cane in the middle of each cordon arm (total of two canes per vine) was measured at the end of each growing season in 2000 and 2001. In each of the four blocks, six central vines were selected for cane growth measurements.

Ten leaves per vine were sampled randomly from the opposite side of basal clusters during full bloom of each cultivar between 6-13 June 2000 and $8-12$ June 2001. Leaves of six vines in each block were combined to make a composite sample of 60 leaves for each of the four blocks. Petioles were separated from blades, and fresh weights of these tissues were measured. Leaf blade area was measured with an area meter (Li-3100; Li-Cor, Lincoln, Nebr.). Leaf blades and petioles were washed with a mild solution of Liquinox detergent (Alconox, White Plains, N.Y.), rinsed in deionized water, dried at $65^{\circ} \mathrm{C}$, and ground in a grinder (Cyclotec 1093; Teactor, Hoganas, Sweden) to pass through a 40 -mesh screen. Nitrogen concentration of each sample was measured with a LECO NitrogenProtein Determinator (FP-528; LECO Corp., St. Joseph, Mich.). The concentrations of $\mathrm{K}, \mathrm{Ca}, \mathrm{Mg}, \mathrm{Fe}$, zinc $(\mathrm{Zn}), \mathrm{Cu}$, and $\mathrm{Mn}$ were measured by atomic absorption spectrophotometry (Perkin-Elmer 1100 B; Norwalk, Conn.) as described by Chaplin and Dixon (1974) and Jones (1977).

We tested the data and found no significant interaction between years and cultivars. Therefore, we have only reported the average values over the 2 years of 2000 and 2001 in each table. Assumption of normality was evaluated by conducting a univariate analysis for all vine responses in this study. Analyses of variance were conducted by using SAS (SAS Institute, Cary, N.C.), and means were separated using Fisher's least significant difference (LSD) at $P \leq$ 0.05 . Pearson's correlation coefficients among yield and fruit quality attributes, which were previously reported by Fallahi et al. (2005), and leaf blade and petiole parameters including minerals were also computed. 


\section{Results and discussion}

\section{Cane and leaf size}

No differences were observed in cane length of different cultivars (Table 1). 'Merlot 01 ' and 'Sangiovese 04' had larger and heavier leaf blades and petioles than all other cultivars (Table 1). Both clones of 'Cabernet Sauvignon' ('Cabernet Sauvignon 02' and 'Cabernet Sauvignon 04') had smaller blade area and lower blade and petiole fresh and dry weights than other cultivars, and differences were often significant (Table 1). No difference existed among cultivars for percent dry weight of blade (Table 1). However, 'Sangiovese 04' had higher petiole percent dry weight than all other cultivars. 'Sangiovese 04' and 'Merlot 01 ' had similar cane length, but had larger and heavier blades and petioles than all other cultivars, and this may result in lower light penetration in the canopies of these cultivars if the total number of leaves per vine is similar in all cultivars.

\section{Blade and petiole mineral concentrations}

Nitrogen. 'Sangiovese 04' and 'Merlot 01' had higher concentrations of blade $\mathrm{N}$ than all other cultivars (Table
2). 'Merlot 01' also had higher petiole nitrate- $\mathrm{N}$ than all cultivars except 'Chardonnay 29'. Christensen (1984) also found a higher level of petiole nitrate-N in own-rooted 'Merlot' than many other tested cultivars, and that is in agreement with our result.

Although 'Sangiovese 04' leaf blade had higher $\mathrm{N}$ concentration than that of 'Chardonnay 29', its petiole nitrate-N was lower than that of 'Chardonnay 29' (Table 2). Cook and Lider (1964) found that petiole nitrate- $\mathrm{N}$ in 'Chardonnay' was lower than that in 'Sangiovese' (both unidentified clones) in California, which is in contradiction with our result. It is difficult to make a direct comparison between our own-rooted vines with grafted vines in California, and the differences in root systems and environmental conditions could be among the reasons for this contradiction.

In our experiment, there was not a significant correlation between concentrations of blade $\mathrm{N}$ and petiole nitrate-N. The lack of a consistent correlation between blade $\mathrm{N}$ and petiole nitrate- $\mathrm{N}$ should be taken into account when interpreting leaf analysis data. Neither blade $\mathrm{N}$ nor petiole nitrate$\mathrm{N}$ had significant correlations with berry soluble solids, berry size, or length of the cane. However, blade $\mathrm{N}$ concentration had a positive correlation with cluster size (Table 4). Blade $\mathrm{N}$ concentrations also had significant positive correlations with blade area, fresh weight, and dry weight (Table 4). The weak relationship between petiole nitrate- $\mathrm{N}$ and blade $\mathrm{N}$ and many other growth attributes suggest that nitrate- $\mathrm{N}$ may not always be a reliable tool to evaluate $\mathrm{N}$ status of vines. Cook and Lider (1964) found that petiole nitrate- $\mathrm{N}$ was correlated inversely with rainfall pattern from budbreak to bloom. Cook and Lider's report underscores that petiole nitrate$\mathrm{N}$ drops rapidly after an irrigation or rainfall, requiring 10-14 d to recover. Unfortunately, Cook and Lider's recommendation (1964) for the use of petiole nitrate- $\mathrm{N}$ is often used without regard to the rainfall or irrigation factors. Later, Kliewer and Cook (1974) reported that analysis of arginine in canes and fruit juice was a better tool to assess $\mathrm{N}$ status of wine grapes, and that approach merits further study to evaluate cultivar differences.

Blade $\mathrm{N}$ showed a positive correlation with blade $\mathrm{K}$, but a negative correlation with blade $\mathrm{Mg}$. This is

Table 1. Cane length, leaf blade area and blade and petiole fresh and dry and percentage dry weights in six wine grape cultivars grown in southwestern Idaho. ${ }^{\mathrm{z}}$

\begin{tabular}{|c|c|c|c|c|c|c|c|c|}
\hline Cultivar & $\begin{array}{l}\text { Cane } \\
\text { length } \\
(\mathrm{cm})^{\mathrm{y}}\end{array}$ & $\begin{array}{c}\text { Leaf blade } \\
\text { area } \\
\left(\mathrm{cm}^{2} / \text { leaf }\right)^{y}\end{array}$ & $\begin{array}{c}\text { Blade } \\
\text { fresh wt } \\
(\mathrm{g} / \text { leaf })^{y}\end{array}$ & $\begin{array}{c}\text { Blade } \\
\text { dry wt } \\
\text { (g/leaf) }\end{array}$ & $\begin{array}{c}\text { Blade } \\
\text { dry wt } \\
(\% \text { fresh wt })\end{array}$ & $\begin{array}{c}\text { Petiole } \\
\text { fresh wt } \\
(\mathrm{mg} / \text { petiole })\end{array}$ & $\begin{array}{c}\text { Petiole } \\
\text { dry wt } \\
\text { (mg/petiole) }\end{array}$ & $\begin{array}{c}\text { Petiole } \\
\text { dry wt } \\
\text { (\% fresh wt) }\end{array}$ \\
\hline Cabernet Sauvignon 02 & $56 a$ & $88 \mathrm{~d}$ & $1.84 \mathrm{~d}$ & $0.51 \mathrm{c}$ & $27.5 \mathrm{a}$ & $400 \mathrm{c}$ & $55 \mathrm{c}$ & $14.1 \mathrm{~b}$ \\
\hline Cabernet Sauvignon 04 & $55 \mathrm{a}$ & $92 \mathrm{~cd}$ & $1.89 \mathrm{~cd}$ & $0.53 c$ & $28.6 \mathrm{a}$ & $408 \mathrm{c}$ & $48 c$ & $13.2 \mathrm{bc}$ \\
\hline Chardonnay 29 & $68 \mathrm{a}$ & $114 \mathrm{~b}$ & $2.30 \mathrm{~b}$ & $0.64 \mathrm{~b}$ & $27.9 \mathrm{a}$ & $535 \mathrm{~b}$ & $73 \mathrm{~b}$ & $13.9 \mathrm{bc}$ \\
\hline Sangiovese 04 & $81 \mathrm{a}$ & $137 \mathrm{a}$ & $3.21 \mathrm{a}$ & $0.86 \mathrm{a}$ & $26.9 \mathrm{a}$ & 708 a & $106 \mathrm{a}$ & $15.2 \mathrm{a}$ \\
\hline
\end{tabular}

${ }^{2}$ Mean separation within columns using Fisher's least significant difference at $P \leq 0.05$. Each value is the average over 2 years $(2000$ and 2001$)$, each year with four blocks, and each block with six vines.

${ }^{y} 1 \mathrm{~cm}=0.3937$ inch; $1 \mathrm{~cm}^{2}=0.1550$ inch $^{2} ; 1 \mathrm{~g}=0.0353 \mathrm{oz} ; 1 \mathrm{mg}=3.5274 \times 10^{-5} \mathrm{oz}$.

Table 2. Leaf blade and petiole nitrogen $(\mathrm{N})$, potassium $(\mathrm{K})$, calcium $(\mathrm{Ca})$ and magnesium $(\mathrm{Mg})$ concentrations in six wine grape cultivars grown in southwestern Idaho. ${ }^{\mathrm{z}}$

\begin{tabular}{|c|c|c|c|c|c|c|c|c|}
\hline \multirow[b]{2}{*}{ Cultivar } & \multirow{2}{*}{$\begin{array}{c}\mathrm{N} \\
(\% \text { dry wt }) \\
\text { Blade }\end{array}$} & \multirow{2}{*}{$\begin{array}{c}\text { Nitrate-N } \\
{\left[\mu \mathrm{g} \cdot \mathrm{g}^{-1}(\mathrm{ppm})\right]} \\
\text { Petiole }\end{array}$} & \multicolumn{2}{|c|}{ K (\% dry wt) } & \multicolumn{2}{|c|}{$\mathrm{Ca}(\%$ dry wt) } & \multicolumn{2}{|c|}{$\operatorname{Mg}(\%$ dry wt) } \\
\hline & & & Blade & Petiole & Blade & Petiole & Blade & Petiole \\
\hline Cabernet Sauvignon 02 & $3.16 \mathrm{~b}$ & $785 \mathrm{~b}$ & $1.06 \mathrm{c}$ & $4.23 \mathrm{ab}$ & $2.32 \mathrm{~b}$ & $2.17 \mathrm{a}$ & $0.46 \mathrm{~b}$ & $0.90 \mathrm{a}$ \\
\hline Cabernet Sauvignon 04 & $3.21 \mathrm{~b}$ & $832 \mathrm{~b}$ & $1.17 \mathrm{bc}$ & $4.24 \mathrm{ab}$ & $2.21 \mathrm{bc}$ & $2.12 \mathrm{a}$ & $0.44 \mathrm{~b}$ & $0.84 \mathrm{ab}$ \\
\hline Chardonnay 29 & $3.32 \mathrm{~b}$ & $1633 \mathrm{a}$ & $1.30 \mathrm{ab}$ & $4.08 \mathrm{ab}$ & $1.87 \mathrm{c}$ & $1.39 \mathrm{~b}$ & $0.47 \mathrm{ab}$ & $0.81 \mathrm{ab}$ \\
\hline
\end{tabular}

${ }^{2}$ Mean separation within columns using Fisher's least significant difference at $P \leq 0.05$. Each value is the average over 2 years $(2000$ and 2001$)$, each year with four blocks, and each block with six vines. 
Table 3. Leaf blade and petiole iron $(\mathrm{Fe})$, zinc $(\mathrm{Zn})$, copper $(\mathrm{Cu})$, and manganese $(\mathrm{Mn})$ concentrations in six wine grape cultivars grown in southwestern Idaho. ${ }^{7}$

\begin{tabular}{|c|c|c|c|c|c|c|c|c|}
\hline \multirow[b]{2}{*}{ Cultivar } & \multicolumn{2}{|c|}{$\mathrm{Fe}\left(\mu \mathrm{g} \cdot \mathrm{g}^{-1}\right)^{\mathrm{y}}$} & \multicolumn{2}{|c|}{$\mathrm{Zn}\left(\mu \mathrm{g} \cdot \mathrm{g}^{-1}\right)$} & \multicolumn{2}{|c|}{$\mathrm{Cu}\left(\mu \mathrm{g} \cdot \mathrm{g}^{-1}\right)$} & \multicolumn{2}{|c|}{$\operatorname{Mn}\left(\mu \mathrm{g} \cdot \mathrm{g}^{-1}\right)$} \\
\hline & Blade & Petiole & Blade & Petiole & Blade & Petiole & Blade & Petiole \\
\hline Barbera 02 & $123 \mathrm{a}$ & $19 \mathrm{~b}$ & $21 \mathrm{a}$ & $29 \mathrm{ab}$ & $11.4 \mathrm{a}$ & $8.4 \mathrm{~b}$ & $145 \mathrm{ab}$ & $87.22 \mathrm{a}$ \\
\hline Cabernet Sauvignon 02 & $90 \mathrm{~b}$ & $23 \mathrm{ab}$ & $19 \mathrm{a}$ & $30 \mathrm{ab}$ & $8.9 \mathrm{~b}$ & $8.7 \mathrm{~b}$ & $130 \mathrm{ab}$ & $69.56 \mathrm{a}$ \\
\hline Cabernet Sauvignon 04 & $92 \mathrm{~b}$ & $18 \mathrm{~b}$ & $19 \mathrm{a}$ & $31 \mathrm{ab}$ & $8.8 \mathrm{~b}$ & $8.4 \mathrm{~b}$ & $125 \mathrm{ab}$ & $100.4 \mathrm{a}$ \\
\hline Chardonnay 29 & $95 \mathrm{~b}$ & $26 \mathrm{a}$ & 18 a & $32 \mathrm{ab}$ & $9.7 \mathrm{~b}$ & $9.2 \mathrm{~b}$ & $146 \mathrm{a}$ & $91.42 \mathrm{a}$ \\
\hline Merlot 01 & $92 \mathrm{~b}$ & $21 \mathrm{ab}$ & $21 \mathrm{a}$ & $36 \mathrm{a}$ & $10.1 \mathrm{ab}$ & $11.5 \mathrm{a}$ & $149 \mathrm{a}$ & $105.11 \mathrm{a}$ \\
\hline Sangiovese 04 & $84 \mathrm{~b}$ & $17 \mathrm{~b}$ & $18 \mathrm{a}$ & $20 \mathrm{~b}$ & $9.0 \mathrm{~b}$ & $8.2 \mathrm{~b}$ & $115 \mathrm{~b}$ & $83.22 \mathrm{a}$ \\
\hline
\end{tabular}

${ }^{2}$ Mean separation within columns using Fisher's least significant difference at $P \leq 0.05$. Each value is the average over 2 years $(2000$ and 2001$)$, each year with four blocks, and each block with six vines.

${ }^{y} 1 \mu \mathrm{g} \cdot \mathrm{g}^{-1}=1 \mathrm{ppm}$.

Table 4. Important correlation coefficients ( $r$ ) among leaf blade and petiole nitrogen $(\mathrm{N})$, potassium $(\mathrm{K})$, magnesium $(\mathrm{Mg})$, copper $(\mathrm{Cu})$, and calcium $(\mathrm{Ca})$ in wine grapes grown in southwestern Idaho.

\begin{tabular}{lc}
\hline Comparisons & $\mathbf{r}^{\mathrm{z}}$ \\
\hline Blade N vs. Cluster Size & $0.47^{*}$ \\
Blade N vs. Blade Area & $0.89^{* *}$ \\
Blade N vs. Blade Fresh Wt & $0.92^{* *}$ \\
Blade N vs. Blade Dry Wt & $0.91^{* *}$ \\
Blade N vs. Blade K & $0.66^{* *}$ \\
Blade N vs. Blade Mg & $-0.51^{*}$ \\
Petiole Nitrate-N vs. Blade K & $0.79^{* *}$ \\
Petiole Nitrate-N vs. Blade Cu & $0.65^{* *}$ \\
Blade K vs. Blade Area & $0.71^{* *}$ \\
Blade K vs. Blade Fresh Wt & $0.60^{* *}$ \\
Blade K vs. Blade Dry Wt & $0.61^{* *}$ \\
Blade K vs. Blade N & $0.66^{* *}$ \\
Blade K vs. Blade Ca & $-0.50^{*}$ \\
Blade K vs. Petiole K & $0.30^{\text {*s }}$ \\
Petiole K vs. Cluster Wt & $-0.54^{*}$ \\
Petiole K vs. Berry Wt & $-0.57^{*}$ \\
Petiole K vs. Yield per Vine & $-0.58^{*}$ \\
Petiole K vs. Cane Length & $-0.58^{*}$ \\
Petiole K vs. Petiole Cu & $0.60^{* *}$ \\
Blade Ca vs. Petiole Ca & $0.74^{* *}$ \\
\hline ss, ***Nonsiginificant or significant at 0.05 or 0.01 \\
respectively. &
\end{tabular}

perhaps due to antagonism between $\mathrm{K}$ and $\mathrm{Mg}$ as previously reported in apple leaves (Fallahi and Simons, 1993). Also, petiole nitrate- $\mathrm{N}$ had positive and strong correlations with blade $\mathrm{K}$ and blade Cu concentrations (Table 4). The physiological factors responsible for the strong correlations observed between petiole nitrate- $\mathrm{N}$ and blade $\mathrm{K}$ and blade $\mathrm{Cu}$ have not been identified, which merits further study. No other significant correlations existed between petiole nitrate- $\mathrm{N}$ and other blade or petiole mineral nutrients.

In this experiment, we did not detect measurable nitrate- $\mathrm{N}$ in blade tissues of different cultivars, which in- dicates that most of the total $\mathrm{N}$ in the blade was in ammonium and organic $\mathrm{N}$ forms.

Robinson (1999) has compiled data from various researchers and reported threshold levels for grape petioles and blade mineral concentrations. In that report, petiole tissues with less than $340 \mu \mathrm{g} \cdot \mathrm{g}^{-1}$ nitrate-N are considered to be deficient and those with more than $2000 \mu \mathrm{g} \cdot \mathrm{g}^{-1}$ are considered to be excessive in California. Although petioles of 'Merlot 01' had slightly more than $2000 \mu \mathrm{g} \cdot \mathrm{g}^{-1}$ nitrate- $\mathrm{N}$ in both years, we did not see any symptoms of leaf toxicity in this or any other cultivars during the study. Our observation in 'Merlot 01' contradicts the high threshold petiole nitrate- $\mathrm{N}$ levels for California in Robinson's report (1999). Therefore, the optimal nitrate- $\mathrm{N}$ threshold levels for each cultivar under regional conditions may need to be studied in more detail.

At this time, we do not have any information on the influence of different levels of $\mathrm{N}$ fertilizers on vine performance in each of these cultivars. 'Cabernet Sauvignon 02' had lower yield than other cultivars (Fallahi et al., 2005) and had relatively lower petiole nitrate-N (Table 2). It would be interesting to see whether addition of a $\mathrm{N}$ fertilizer and increasing the leaf nitrate- $\mathrm{N}$ levels up to about $1500 \mu \mathrm{g} \cdot \mathrm{g}^{-1}$ in 'Cabernet Sauvignon 02' would increase the yield, as reported for 'White Riesling' grape in Washington (Spayd et al., 1993), and if the fruit quality would be affected at that level of nitrate-N. However, it seems that petiole nitrate- $\mathrm{N}$ concentrations in different cultivars are not necessarily proportional to their yield. For example, 'Merlot 01' with petiole nitrate-N concentration of $2067 \mu \mathrm{g} \cdot \mathrm{g}^{-1}$ (the highest among all cultivars, Table
2) produced a total of $12 \mathrm{~kg} /$ vine, while 'Barbera 02' with nitrate- $\mathrm{N}$ of $808 \mu \mathrm{g} \cdot \mathrm{g}^{-1}$ (Table 2 ) produced 17.6 $\mathrm{kg}$ /vine over the 2 years of 2000 and 2001 (Fallahi et al., 2005).

Potassium, CALCIUM, AND MAGNEsIUM. All cultivars had sufficient levels of blade and petiole $\mathrm{K}, \mathrm{Ca}$, and $\mathrm{Mg}$ when compared to standards reported by Robinson (1999). Potassium and $\mathrm{Mg}$ concentrations in blades were lower than those in petioles in all cultivars (Table 2). 'Merlot 01' had the highest average $\mathrm{K}$ concentrations in both blade and petiole tissues among all cultivars, although differences were not always significant (Table 2). High blade K has been reported to cause earlier cane maturity (Cook, 1966). Early root establishment and cane maturity could lead to a better winter survival during early years of planting under the climatic conditions of southwestern Idaho. The relationship between leaf minerals, particularly blade $\mathrm{K}$ and winter survival in different cultivars needs further study. Survival of a red wine grape in the region is particularly important, as many of the red wine cultivars were severely damaged during late Dec. 1990 when temperatures plunged down to $-20^{\circ} \mathrm{F}$. (National Climatic Data Center, 1990).

'Chardonnay 29' had lower concentrations of $\mathrm{Ca}$ and 'Sangiovese 04' had lower concentrations of $\mathrm{Mg}$ in both blade and petiole tissues than other cultivars although differences were not always significant (Table 2). Low petiole Mg in 'Sangiovese 04' is in agreement with Cook and Lider (1964). However, in contrast to our results, petiole Ca in 'Sangiovese' was similar to that of 'Chardonnay' (both unidentified clones) in California (Cook and Lider, 1964), perhaps due to clonal, root system, or environmental differences. 
The average $\mathrm{K}$ value in wine was reported to be in $0.81 \mathrm{~g} \cdot \mathrm{L}^{-1}$ in 101 Australian white wines (Rankine, 1965) and in 24 Italian wines (Amerine and Joslyn, 1970). The average levels of wine $\mathrm{Ca}, \mathrm{Mg}$, and $\mathrm{Zn}$ are also reported by these researchers. Concentrations of these minerals in must and wine and their association with blade and petiole minerals could play an important role in the wine quality, and this area deserves further study for the wine grapes produced in the intermountain western U.S.

Positive correlations were found between leaf blade area and blade $\mathrm{K}$ concentrations, and between blade $\mathrm{K}$ and blade fresh and dry weights (Table 4). In apples, fruit tissues compete with leaves for absorption of $\mathrm{K}$ (Fallahi and Simons, 1993). If the relationship between leaf and fruit in grapes is similar to apples, grape cultivars with larger leaf blade and/or a higher number of leaves could have less $\mathrm{K}$ in their fruit tissues than those with smaller and/or fewer leaves, as leaves would have a greater demand for $\mathrm{K}$. Also, cultivars with higher yield, such as 'Barbera 02' and Sangiovese 04' (Fallahi et al., 2005), had lower petiole $\mathrm{K}$ (Table 2), which is consistent with a previous report from California (Christensen, 1984). Overall, a significant negative correlation coefficient existed between petiole $\mathrm{K}$ and yield per vine (Table 4 ). Fruit $\mathrm{K}$ status may affect wine quality (Amerine and Joslyne, 1970), and thus this area deserves further investigation. Correlations between petiole $\mathrm{K}$ and blade area, blade fresh and dry weights were nonsignificant (data not shown).

Blade $\mathrm{K}$ was positively correlated with blade $\mathrm{N}$ but was negatively correlated with blade $\mathrm{Ca}$ (Table 4 ). There was a significant positive correlation between blade $\mathrm{Ca}$ and petiole $\mathrm{Ca}$. This would suggest that either petiole or blade tissues at bloom can be sampled for determination of $\mathrm{Ca}$ status in wine grapes. The correlation coefficient between blade $\mathrm{K}$ and petiole $\mathrm{K}$ was not significant. Significantly negative correlations were found between petiole $\mathrm{K}$ and cluster weight, berry weight, yield, and cane length (Table 4). However, correlations between blade $\mathrm{K}$ and berry weight and cluster weight were nonsignificant (data not shown).

BLADE AND PETIOLE MICRONUTRIENTS. Blade $\mathrm{Zn}$ in all cultivars, petiole $\mathrm{Zn}$ in 'Snagivese 04', and blade $\mathrm{Cu}$ in all cultivars, except 'Barbera 02' and
'Merlot 01' were in deficient ranges according to the grape leaf standards of Robinson (1999). Concentrations of blade Fe and $\mathrm{Mn}$ were higher while blade $\mathrm{Zn}$ was lower than those of petioles in all cultivars (Table 3). Lower $\mathrm{Zn}$ in the blade tissue as compared to the petiole tissue is in agreement with an earlier report from California (Christensen, 1984). Blade Fe levels for all cultivars were higher in 2001 than in 2000 (data not shown), perhaps because vines had a more extensive root system and hence were more efficient in Fe uptake in 2001.

'Barbera 02' had higher blade Fe (Table 3 ) and tended to have higher blade $\mathrm{Cu}$ (Table 3 ). However, 'Chardonnay 29' had higher petiole Fe than 'Barbera 02', 'Cabernet Sauvignon 04', and 'Sangiovese 04' (Table 3). The ability to absorb higher levels of Fe, $\mathrm{Zn}$, and $\mathrm{Cu}$ is important as these elements, particularly $\mathrm{Zn}$, are commonly deficient in the high soil $\mathrm{pH}$ conditions prevalent in southwestern Idaho.

'Merlot 01' and 'Chardonnay 29' had significantly higher blade Mn than 'Sangiovese 04'. Other than that, there was no clear trend in the blade and petiole Mn levels for any cultivar (Table 3).

Positive correlations existed between micronutrient concentrations in blade and concentrations of the same element in the petiole tissue, with the values often being significant (data not shown). Also, a significant positive correlation was found between petiole $\mathrm{K}$ and petiole $\mathrm{Cu}$ concentrations (Table 4). Since petiole nitrate- $\mathrm{N}$ also had strong correlation with blade $\mathrm{K}$ and blade $\mathrm{Cu}$, and at the same time blade $\mathrm{N}$ had a significant correlation with petiole $\mathrm{K}$ as described earlier, it is difficult to explain a physiological association for these relationships.

Although there have been some 500 reports on trace elements content of must and wine between 1900 to 1965 (Amerine and Joslyn, 1970), there is no information on wine concentrations of any minerals for the intermountain western U.S. The relationship between leaf and fruit mineral status with those of must and wine in the region deserves further investigation.

\section{General comments}

Own-rooted 'Barbera 02' could be a good choice for planting in areas with Fe deficiency problems, as it had higher blade Fe (Table 3 ), and it had relatively high tolerance to low winter temperatures at the Colorado State University Orchard Mesa Research Center (Hamman, 1993). However, since a substantial amount of $\mathrm{K}$ is needed for a full crop production in wine grapes (Cook, 1966), relatively low Klevels in 'Barbera 02' blades and petioles (Table 2 ) could ultimately lead to lower production if soil or foliar $\mathrm{K}$ is not supplemented when vines get older. Wine produced from 'Chardonnay 29' received favorable ratings and there were sufficient heat units to mature the fruit (Fallahi et al., 2005). This cultivar also had relatively high tolerance to low winter temperatures (Hamman, 1993), and thus recommended for planting in southwestern Idaho. Further studies are needed to see if the relatively lower foliar Ca in 'Chardonnay 29' (Table 2 ) is associated with its wine quality. High levels of $\mathrm{N}$ in blade and petiole of 'Merlot 01' could be advantageous, as soils have naturally low $\mathrm{N}$ content in southwestern Idaho.

Production of high quality wine in today's competitive and global market is critical. General nutrient concentration standards developed by averaging values for several regions and cultivars may provide broad guidelines but may not be adequately precise for producing quality wine grapes in each region. Similar to the conclusions made by Christensen (1984), the results in this report underscore the needs for developing foliar nutrient standards for each commercially important cultivar in each geographical region. Evaluation of certain commercial cultivars under climatologically similar areas would reveal how consistent the cultivar differences are. This area deserves further study.

\section{Literature cited}

Adams, L.D. 1985. The wines of America, 3rd ed. McGraw-Hill, New York.

Amerine, M.A. and M.A. Joslyn. 1970. Composition of table wines, p. 431-493. In: Table wines. Univ. of California Press, Berkeley.

Cahoon, G.A. 1996. History of the French hybrid grapes in northern America. Fruit Var. J. 50:202-216.

Chaplin, M.H. and A.R. Dixon. 1974. A method for analysis of plant tissue by direct reading spark emission spectroscopy. Appl. Spectroscopy 28:5-8. 
Christensen, P. 1984. Nutrient level comparisons of leaf petioles and blades in twenty-six grape cultivars over three years (1979-1981). Amer. J. Enol. Viticult. 35:124-133.

Cook, J.A. 1966. Grape nutrition, p. 777-812. In: N. Childers (ed.). Temperate to tropical fruit nutrition. Horticultural Publ., New Brunswick, N.J.

Cook, J.A. and L.A. Lider. 1964. Mineral composition of blooming grape petiole in relation to rootstock and scion variety behavior. Proc. Amer. Soc. Hort. Sci. 84:243-254.

Downton, W.J. 1977. Influence of rootstocks on the accumulation of chloride, sodium, and potassium in grape vines. Austral. J. Agr. Res. 28:879-889.

Evans, R.G. S.E. Spayed, R.L. Wample, M.W. Kroeger, and M.O. Mahan. 1993. Water use of Vitis vinifera grapes in Washington. Agr. Water Mgt. 23:109-124.

Evans, R.G. 1999. Irrigation choices for Vitisvinifera grapes in eastern Washington, p. 57-74. In: J. Watson (ed.). Growing grapes in eastern Washington. Good Fruit Grower, Yakima, Wash.

Fallahi, E., B. Shafii, B. Fallahi, J.C. Stark, and A.L. Engle. 2004. Yield, quality attributes, and degree day requirements of various wine grapes under climatic conditions of intermountain west region. J.Amer. Pomol. Soc. 58: 156-162.

Fallahi, E., B. Fallahi, B. Shafii, and J.C. Stark. 2005. Performance of six wine grapes under southwest Idaho environmental conditions. Small Fruit Rev. 4:77-85.

Fallahi, E. and B. R. Simons. 1993. Influence of fruit spacing on fruit quality and mineral partitioning of 'Redchief Delicious' apple under full crop conditions. Fruit Var. J. 47:172-178.

Goldspink, G.H. 1987. Grape vine nutrient analysis services and basis for standard in Western Australia, p. 5-19. In: T.H. Lee and B.M. Freeman (eds.). Vine nutrition. Proc. Austral. Soc. Viticult. Enol. Seminar, 31 July 1987. Austral. Wine Res. Inst., Glen Osmond, South Australia.
Hamman, R.A., Jr. 1993. Wine grape performance of 32 cultivars in western Colorado 1982-1986. Fruit Var. J. 47: 59-63.

Idaho Agricultural Statistics Service. 2003. Idaho agricultural statistics. Idaho Dept. Agr., Boise.

Jones, B.J. 1977. Elemental analysis of soil extracts and plant tissue ash by plasma emission spectroscopy. Commun. Soil Sci. Plant Anal. 8:349-365.

Kaps, M.L. and M.B. Odneal. 2001. Grape cultivar performance in the Missouri Ozark region. J. Amer. Pomol. Soc. 5:34-44.

Kliewer, M. and J.A. Cook. 1974. Arginine levels in grape canes and fruits as indicators of nitrogen status of vineyards. Amer. J. Enol. Viticult. 25:111-118.

Mielke, E.A. 1980. Grape and wine production in the Four Corners region. Univ. of Arizona Tech. Bul. 239.

Pinney, T. 1989. A history of wine in America. Univ. of California Press, Berkeley.

Rankine, B.C. 1965. Ion-exchange treatment of wine. Austral. Wine Brewing Spirit Rev. 85:59-62.

Robinson, J.B. 1999. Grape nutrition, p. 178-208. In: B.G. Coombe and P.R. Dry (eds.). Viticulture, vol. 2, practices. Hyde Park Press, Adelaide, South Australia.

Sexton, J. 1987. History of the fruit industry in Mesa County. Proc. Western Colorado Hort. Soc. 44:92-98.

Shock, C.C., J.M. Barnum, and M. Seddigh. 1998. Calibration of Watermark soil moisture sensors for irrigation management. Proc. Intl. Irr. Show, Irr. Assn., San Diego. p. 139-146.

Somers, T.C. 1975. In search of quality for red wines. Food Technol. Australia $27: 49-56$.
Spayd, S.E., R.L. Wample, R.G. Stevens, R.G. Evans, and A.K. Kawakami. 1993. Nitrogen fertilization of 'White Riesling' in Washington: Effects on petiole nutrient concentration, yield, yield components, and vegetative growth. Amer. J. Enol. Viticult. 44:378-386.

National Climatic Data Center. 1990. Temperature extremes and freeze data, Idaho climatological data annual summary, 93:12. Dept. of Commerce, Natl. Oceanic and Atmospheric Administration, Asheville, N.C.

Ulrich, A. 1942. Nitrate-N content of grape petioles as an indicator of the $\mathrm{N}$ status of the plant. Proc. Amer. Soc. Hort. Sci. 41:213-218.

Wample, R.L. 1999. Water relations and irrigation management of wine grapes, p. 75-81. In: J. Jackson (ed.). Growing grapes in eastern Washington. Good Fruit Grower, Yakima, Wash.

Weir, R.G. 1987. Grape vine nutrient analysis services and basis for standard in NSW, p. 41-47. In: T.H. Lee and B.M. Freeman (eds.). Vine nutrition. Proc. Austral. Soc. Viticult. Enol. Seminar, 31 July 1987. Austral. Wine Res. Inst., Glen Osmond, South Australia.

Winkler, A.J., J.A. Cook, W.M. Kliewer, and L.A. Lider. 1974. General viticulture. Univ. of California Press, Berkeley.

Wolf, T.K. and M.K. Miller. 2001. Crop yield, fruit quality, and winter injury of 12 red-fruited wine grape cultivars in northern Virginia. J. Amer. Pomol. Soc. 55:24l-250. 